\title{
JUBULA HUTCHINSIAE SUBSP. CAUCASICA KONSTANT. \& VILNET (MARCHANTIOPHYTA: JUBULACEAE) - NEW FOR THE BRYOPHYTE FLORA OF IRAN AND TURKEY
}

\author{
HARALD KÜRSCHNER
}

\begin{abstract}
Jubula hutchinsiae (Hook.) Dumort. forms a complex of notoriously difficult intraspecific taxa, recorded from Southwest Asia as J. hutchinsiae subsp. javanica (Steph.) Verd. A re-examination of the Iranian and Turkish records indicates that they belong to the recently described J. hutchinsiae subsp. caucasica Konstant. and Vilnet, which seem to be restricted to the broadleaved deciduous forests of the Euxine-Caucasian-Hyrcanian floral province.
\end{abstract}

Key words: Bryoflora, Euxine-Caucasian-Hyrcanian floral province, liverworts, phytogeography.

Harald Kürschner, Freie Universität Berlin, Institut für Biologie, Systematische Botanik und Pflanzengeographie, Altensteinstr. 6, D-14195 Berlin, Germany

\section{INTRODUCTION}

Despite the monograph of Guerke (1978), there has long been great confusion about assignment of the highly polymorphic Jubula Dumort. species recorded from Southwest Asia and the Caucasus. The first records of this taxon date back to Brotherus (1892), who reported the genus from Georgia (Caucasus) as Frullania hutchinsiae (Hook.) Nees var. integrifolia (Nees) Lindb. Later on, records from Southwest Asia and the Caucasus area were named either as Jubula hutchinsiae (Hook.) Dumort. subsp. pennsylvanica Verd. [J. pennsylvanica (Steph.) A. Evans (Zerov 1953)] or more often as J. hutchinsiae subsp. javanica (Steph.) Verd. (cf. Kürschner \& Frey 2011). As Guerke (1978) treated $J$. hutchinsiae subsp. pennsylvanica as a strictly East-American endemic, most authors followed this phytogeographical concept and listed all records from Southwest Asian to the present under the EastAsian J. hutchinsiae subsp. javanica, even though most of the specimens lack any serration of the leaf lobes and underleaves typical for J. hutchinsiae subsp. javanica, thus more resembling J. hutchinsiae subsp. pennsylvanica. Only in the Caucasus Mts have such specimens with entire leaf lobes been referred to J. hutchinsiae subsp. pennsyl- vanica (Zerov 1953; Duda 1982). The confusion is deepened, as specimens with entire leaf lobes and underleaves also were known from J. hutchinsiae subsp. javanica, and named $J$. hutchinsiae var. integrifolia S. Hattori. The latter taxon, however, deserves no taxonomic recognition in the view of most authors (Frey et al. 2006; Guerke 1978; Kürschner \& Frey 2011; Paton 1999).

The classification within (sub)tropical J. hutchinsiae subsp. javanica is supported additionally by the floral history of the area and the phytogeographical concept of 'Indo-Malesian relict species', as indicated by many vascular plants that survived the strong Pleistocene climatic changes in forest refuges along the eastern Black Sea and Caspian Sea coasts (Euxine-Colchic-Hyrcanian relict forests; cf. Zohary 1973). By this view, $J$. hutchinsiae subsp. javanica represents a nice example for these phytogeographical relationships within the bryophytes.

Just recently, Konstantinova and Vilnet (2011) described a new subspecies in the Jubula hutchinsiae complex of the Russian western Caucasus mountains (Republic of Adygea). Based on ITS1-2, nrDNA, trnL-F and trnG cpDNA 
sequences and some morphological characters it turned out that all specimens from the Russian Caucasus area belong to an own taxon, named $J$. hutchinsiae subsp. caucasica, which evolved in the perhumid, subtropical Colchic lowland forests. It is also confirmed for Georgia (Adjara, Mtirala National Park and Jochostskali area east of Batumi; Kürschner et al. 2013). Therefore it can be expected that most records in the area belong to this new taxon and are hidden until now under the East-Asian J. hutchinsiae subsp. javanica (cf. Kürschner \& Frey 2011) as already stated by Konstantinova and Vilnet (2011). A re-examination of the Iranian (Frey \& Kürschner 1983) and Turkish records confirmed this view.

\section{RESULTS}

Morphology. Katagiri et al. (2010) showed that J. hutchinsiae subsp. javanica can be separated from $J$. hutchinsiae subsp. pennsylvanica by (mostly) serrate leaf lobules, small and short male branches and thick-walled medulla cells in stem cross-section. By contrast, the new J. hutchinsiae subsp. caucasica has entire leaf lobules, large and long male branches and thin-walled medulla cells, thus much more resembling $J$. hutchinsiae subsp. pennsylvanica morphologically. The latter is clearly separated by the molecular data and in addition by some (weak) morphological differences which can be summarized as follows (cf. Konstantinova \& Vilnet 2011):

-J. hutchinsiae subsp. caucasica - small leaf lobes; sinus of bracts with slightly to non-reflexed margins; underleaves only shortly decurrent (decurrent part $<$ width of stem); a distinct smallcelled zone on the stem between the decurrent underleaf lobes.

- J. hutchinsiae subsp. pennsylvanica - larger leaf lobes; sinus of bracts with strongly reflexed margins; underleaves long decurrent (decurrent part $>$ width of stem); lack of a distinct smallcelled zone on the stem between the decurrent underleaf lobes.

A re-examination of the known Iranian records (Frey \& Kürschner 1983) and some Turkish sam- ples from eastern Karadeniz Dağları close to the Georgian border shows that the samples fit well in the morphological concept given by Konstantinova and Vilnet (2011) and therefore belong to this recently described new Euxine-CaucasianHyrcanian taxon.

Jubula hutchinsiae (Hook.) Dumort. subsp. caucasica Konstant. \& Vilnet

New to Iran and Turkey (Fig. 1).

SPECIMENS EXAMINED: IRAN. MAZANDARAN: Alborz Mts, $12 \mathrm{~km}$ south of Abas Abad, 36 $37^{\prime} 17.9^{\prime \prime} \mathrm{N}$, $51^{\circ} 06^{\prime} 8.1^{\prime \prime} \mathrm{E}$, Caspian (Hyrcanian) lowland forest dominated by Fagus orientalis and Parrotia persica, $400 \mathrm{~m}$, on wet rock, 6 June 1977, O. Braune \& H. Kürschner 77-51 (Frey \& Kürschner 1983 as J. hutchinsiae subsp. javanica); ditto $-36^{\circ} 35^{\prime} 53.9^{\prime \prime} \mathrm{N}, 51^{\circ} 07^{\prime} 58.4^{\prime \prime} \mathrm{E}, 700 \mathrm{~m}$, on wet rock, 6 June 1977, O. Braune \& H. Kürschner 77-61 (Frey \& Kürschner 1983 as J. hutchinsiae subsp. javanica). TURKEY. TRABZON: Karadeniz Dağları, $12 \mathrm{~km}$ south of Of, near Çumarpazarı, $40^{\circ} 49^{\prime} 21^{\prime \prime} \mathrm{N}$, $40^{\circ} 16^{\prime} 06^{\prime \prime} \mathrm{E}, 130 \mathrm{~m}$, on rock near waterfall in Euxine lowland forest, 22 June 2011, M. Kırmacı \& H. Kürschner 11-135; Rize: Karadeniz Dağları, Ikizdere, near Şimşirlıköyü, $40^{\circ} 48^{\prime} 31.8^{\prime \prime} \mathrm{N}, 40^{\circ} 29^{\prime} 41.2^{\prime \prime} \mathrm{E}, 960 \mathrm{~m}$, on wet rock in Euxine lowland forest dominated by Fagus orientalis, 16 Sept. 2004, H. Kürschner \& G. Parolly 04-983; ditto - between Çayelı and Kaptanpaşa, near Yeşiltepe, $40^{\circ} 58^{\prime} 01^{\prime \prime} \mathrm{N}$ ', $40^{\circ} 47^{\prime} 44.9^{\prime \prime} \mathrm{E}, 430 \mathrm{~m}$, Euxine lowland forest, on wet rock beneath Rhododendron ponticum scrub, 23 June 2011, M. Kırmacı \& H. Kürschner 11-146.

PhytogeOgRAPHY AND ECOLOGY. Jubula hutchinsiae subsp. caucasica belongs to a small group of partly endemic saxicolous and corticolous species that survived and evolved under subtropical climate conditions in the forests of the eastern Black Sea coast, the lower parts of the Caucasus Mts and the southern Caspian Sea area (Fig. 1). This florogenetic entity can be combined into a Euxine-Caucasian-Hyrcanian floral province of the large Euro-Siberian region [Frey 1980; Pontic province of the Euro-Siberian region (West EuroSiberian subregion) sensu Zohary 1973 p. 81]. To the present day this area is densely covered by hygro-thermophytic and mesophytic broadleaved deciduous lowland and montane forests dominated by Fagus orientalis Lipsky (Fig. 1), and associated 


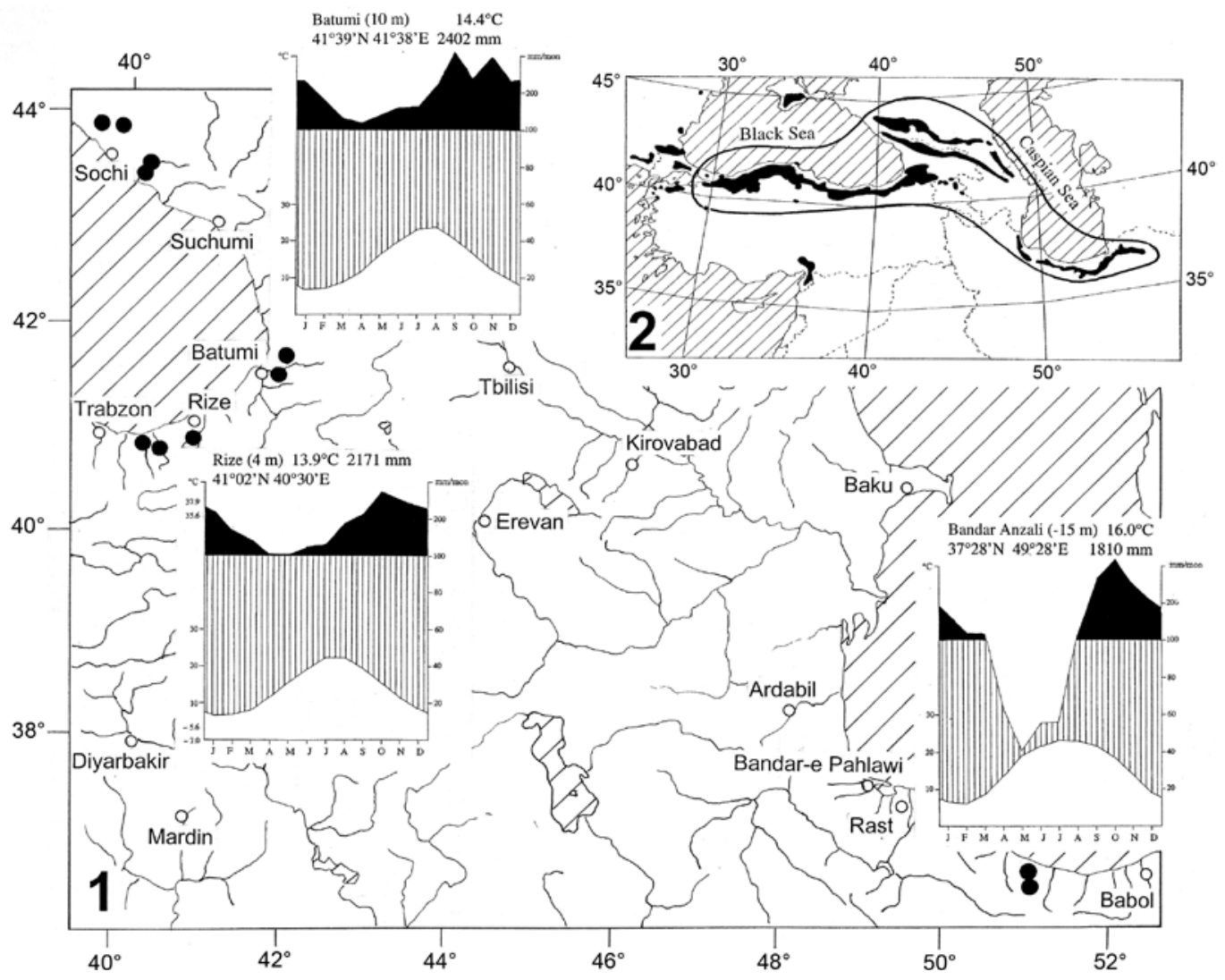

Fig. 1.1 - Distribution of Jubula hutchinsiae subsp. caucasica Konstant. \& Vilnet in the Caucasus and Southwest Asia (records near Sochi after Konstantinova \& Vilnet 2011; records near Batumi after Kürschner et al. 2013; Turkish and Iranian records hoc loco; climate diagrams after Alex 1984). 2 - Euxine-Caucasian-Hyrcanian floral province sensu Frey 1980, and distribution of Fagus orientalis Lipsky (based on EUFORGEN Networks, http://www.euforgen.org).

with substantial components of evergreen shrub in the understorey. These forests are sometimes considered warm-temperate rainforests (Nakhutsrishvili et al. 2010) which harbor a great number of relicts of Arcto-Tertiary and palaeotropical IndoMalesian origin. Here they survived in situ the Tertiary aridization and the glaciations during the Pleistocene. Examples of vascular plants indicating these relationships, which began to spread from Southeast Asia in the Cretaceous, reaching Europe in the early Tertiary, include Acer cappadocicum Gled., Albizia julibrissin Durazz., Alnus subcordata C. A. Mey., Buxus spp., Danae racemosa (L.) Moench, Dioscorea caucasica Lipsky, Diospyros lotus L., Fagus orientalis Lipsky, Ficus colchica Grossh., Gleditsia caspica Desf., Hedera colchica
(K. Koch) K. Koch, H. pastuchovii Woronow, Ilex colchica Pojark., I. spinigera (Loes.) Loes., Mespilus germanica L., Parrotia persica C. A. Mey., Prunus laurocerasus L., Pterocarya fraxinifolia Spach, Pyracantha coccinea M.Roem., Quercus castaneifolia C. A. Mey., Q. hartwissiana Steven, Q. pontica C. Koch \& K. Koch, Q. robur (Ten.) A.DC. subsp. imeretina Menitsky, Rhododendron ponticum L., R. ungernii Trautv. ex Regel, Viburnum orientale Pall. and Zelkova carpinifolia (Pall.) $\mathrm{K}$. Koch. All this makes the whole area an outstanding and important Arcto-Tertiary refuge area (Probst 1981; Browicz 1989; Frey et al. 1999; Milne \& Abbott 2002; Milne 2006).

The liverworts and mosses following this distributional pattern are few but include some 

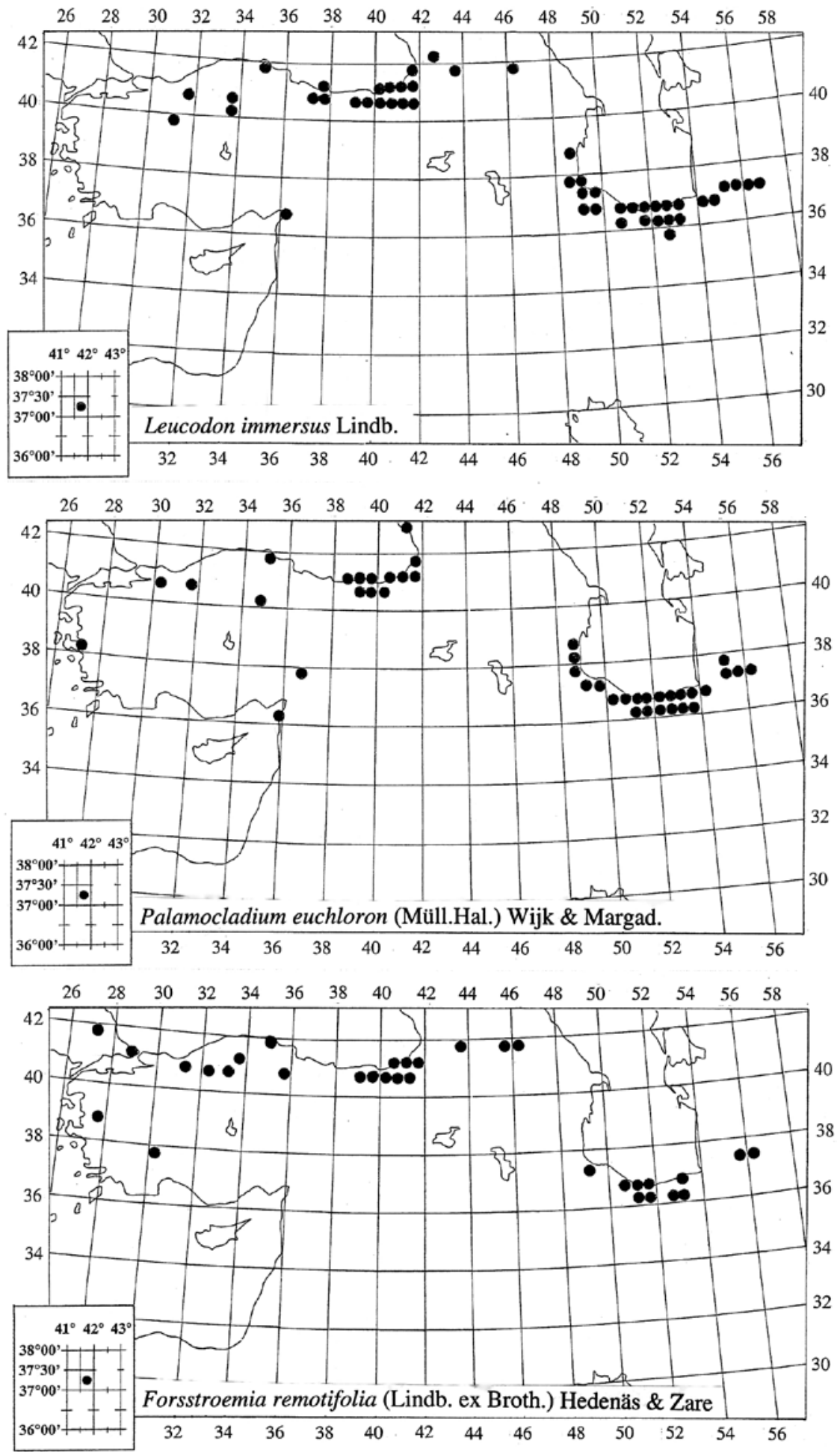
interesting saxicolous and corticolous taxa such as Solenostoma caucasicum (Ván̆a) Konstant., $S$. handelii (Schiffn.) Müll. Frib. (probably a Tertiary relict with exclaves on Crete, in Spain and in Japan), S. lignicola (Schiffn.) Ván̆a, Hentschel \& J. Heinrichs, S. subtilissimum (Schiffn.) R. M. Schust., Forsstroemia remotifolia (Lindb. ex Broth.) Hedenäs \& Zare [syn. Pseudoleskeella laxiramea (Schiffn.) Broth.], Palamocladium euchloron (Müll. Hal.) Wijk \& Margad. and Leucodon immersus Lindb. (the latter two having a wider distribution and exclaves in the Amanos Mts, Turkey) (Fig. 2). They evolved in these relict forests, which are subjected to moist sea winds throughout the year, bringing high summer rainfall and hence lowering the risk of desiccation. Rainfall generally is very high, distributed throughout the whole year with heavy summer rains, amounting to more than $2000 \mathrm{~mm} /$ year in the Euxine and Colchic sectors of the area (e.g., Rize $2171 \mathrm{~mm} /$ year, Batumi $2402 \mathrm{~mm} /$ year; Fig. 1). Towards the east (Hyrcanian sector) and with distance from the sea, rainfall continuously decreases but still is high (e.g., Bandar Anzali $1810 \mathrm{~mm} /$ year), and the climate changes from perhumid to humid conditions. However, mild temperatures, high rainfall and permanent high atmospheric humidity, with damp and often foggy conditions, ensured the establishment of rich epiphytic bryophyte diversity throughout the Euxine-Caucasian-Hyrcanian area (Kürschner et al. 2012), and the evolution of taxa of humid northern (Solenostoma spp.) and (sub) tropical origin, such as Jubula hutchinsiae subsp. caucasica, Forsstroemia remotifolia or Palamocladium euchloron.

ACKNOWLEDGEMENTS. I gratefully acknowledge financial support for field studies by Deutsche Forschungsgemeinschaft (DFG) SFB 19 'Tübinger Atlas des Vorderen Orients', Adnan Menderes Üniversitesi Aydın and Freie Universität Berlin. Special thanks to Adnan Erdağ, Mesut Kırmacı (Adnan Menderes Üniversitesi, Aydın) and Gerald Parolly (Berlin) for their support of the field work in Turkey.

\section{REFERENCES}

ALEX M. 1984. Klimadaten ausgewählter Stationen des Vorderen Orients. Beihefte zum Tübinger Atlas des Vorderer Orient, Reihe A (Naturwissenschaften). 14. Ludwig Reichert Verlag, Wiesbaden.

Brotherus V. 1892. Enumeratio muscorum Caucasi. Acta Soc. Sci. Fenn. 19: 1-170.

BRowicz K. 1989. Chorology of the Euxinian and Hyrcanian element in the woody flora of Asia. Pl. Syst. Evol. 162: 305-314.

DudA J. 1982. Ad distributionem Hepaticarum in Caucaso notula. Novosti Sist. Nizsh. Rast. 19: 200-204.

FREY W. 1980. Wald- und Gebüschverbreitung in NordwestHorasan (Nordiran). Beihefte zumTübinger Atlas Vorderer Orient, Reihe A (Naturwissenschaften). 6. Ludwig Reichert Verlag, Wiesbaden.

FREY W. \& KÜRSCHNER H. 1983. Contributions towards a bryophyte flora of Iran. New records from Iran. Iranian J. Bot. 2: 13-19.

Frey W., KÜRschner H. \& Probst W. 1999. Flora and vegetation, including plant species and larger vegetation complexes in Persia. In: E. YARSHATER (ed.), Encyclopaedia Iranica. 10(1): 46-63. Bibliotheca Persica Press, New York.

Frey W., Frahm J.-P., Fischer E. \& Lobin W. 2006. The liverworts, mosses and ferns of Europe. (Edited by T. L. BLOCKEEL). Harley Books, Colchester.

GuERKE W. R. 1978. A monograph of the genus Jubula Dumortier. Bryophyt. Biblioth. 17: 1-118.

KATAGIRI T., YAMAGUChI T. \& DEGUChI H. 2010. Taxonomic studies on the liverwort Jubula Dumortier (Marchantiophyta: Jubulaceae) in Japan and Taiwan. Hikobia 15: 463-472.

Konstantinova N. A. \& VILnET A. A. 2011. Jubula hutchinsiae subsp. caucasica subsp. nov. (Jubulaceae, Marchantiophyta) - a new taxon from the western Caucasus. Arctoa 20: 227-238.

KÜRSCHNER H. \& FREY W. 2011. Liverworts, mosses and hornworts of Southwest Asia. Marchantiophyta, Bryophyta, Anthocerotophyta. Bryophyt. Biblioth. 139: 1-240.

Kürschner H., Batsatsashvili K. \& Parolly G. 2013. Additions to the bryophyte flora of Georgia. Herzogia 26 (in press).

KÜRSCHNER H., KIRMACI M., ERDAĞ A., BATSATSASHVILI K. \& PAROLLY G. 2012. Ecology and life strategies of epiphytic bryophyte communities from the Arcto-Tertiary

Fig. 2. Leucodon immersus, Palamocladium euchloron and Forsstroemia remotifolia, three selected species with a mainly Euxine-Caucasian Hyrcanian distribution pattern. 
relict forests of the Black and Caspian Sea areas. Nova Hedwigia 94: 31-65.

MiLne R. I. 2006. Northern Hemisphere plant disjunctions: A window on Tertiary land bridges and climate change? Ann. Bot. 98: 465-472.

MiLne R. I. \& ABвotT R. J. 2002. The origin and evolution of Tertiary relict floras. Advances Bot. Res. 38: 281-314.

NAKHUTSRISHVILI G., ZAZANASHVILI N. \& BATSATSASHVILI K. 2010. Regional profile: Colchic and Hyrcanic temperate rainforests of the Western Eurasian Caucasus. In: D. A. Della SAlla (ed.), Temperate and boreal rainforests of the world, pp. 214-221. Island Press, Washington DC.
PATON J. A. 1999. The liverwort flora of the British Isles. Harley Books, Colchester.

Probst W. 1981. Zur Vegetationsgeschichte und Klimaentwicklung des Südkaspischen Waldgebietes (Nordiran). In: W. FREY \& H.-P. UERPMANN (eds), Beiträge zur Umweltgeschichte des Vorderen Orients, pp. 26-39. Beihefte zum Tübinger Atlas Vorderer Orient, Reihe A (Naturwissenschaften). 8. Ludwig Reichert Verlag, Wiesbaden.

ZEROV D. K. 1953. The genus Jubula Dum. in the flora of the USSR. Bot. Zhurn. (Kiev) 10: 85-90 (in Ukrainian).

ZOHARY M. 1973. Geobotanical foundations of the Middle East. 1 \& 2. G. Fischer Verlag, Stuttgart.

Received 8 January 2013 